\title{
Regulation of cell function by isoforms of C-reactive protein: A comparative analysis
}

\author{
Magdalena Boncler and Cezary Watała \\ Department of Hemostasis and Hemostatic Disorders, Medical University of Lodz, Eódź, Poland
}

Received: 20 October, 2008; revised: 12 December, 2008; accepted: 10 February, 2009

available on-line: 12 February, 2009

\begin{abstract}
Despite the emerging evidence suggesting a proatherogenic role of C-reactive protein (CRP) in atherosclerosis, the contribution of CRP in pathogenesis of atherosclerosis and atherothrombosis has not been unequivocally defined. The role of CRP in pathophysiology/pathology seems to largely depend on its structure. Two CRP isoforms, the native pentameric and the modified monomeric one, differ substantially in their physiological functions, which is thought to origin from the considerable structural heterogeneity of the CRP molecule. The present review provides an overview of the experimental evidence with relevance to the clinical role(s) of various CRP isoforms. The biological role of the protein, its structure and distribution are discussed with particular emphasis on the diverse properties of the pentameric and monomeric forms of CRP. Some methodological aspects, related to experimental models and techniques of CRP preparation, are also critically reviewed.
\end{abstract}

Keywords: C-reactive protein, native CRP, modified CRP, inflammation, atherosclerosis

\section{BIOLOGY OF C-REACTIVE PROTEIN}

C-reactive protein was originally discovered by Tillett and Francis (1930) in sera from patients with Streptococcus pneumonia infection. Its name derives from the interaction with phosphocholine (PCh) residues of pneumococcal C-polysaccharide (PnC), a component of teichoic acid in the pneumococcal cell wall. The binding of phosphocholine and the complement pathway component (C1q) by CRP is part of innate immunity that activates the classical com- plement pathway (Gabay \& Kushner, 1999; Du Clos, 2000). The interactions between CRP and its various ligands, like phosphocholine or $\mathrm{Fc} \gamma$ receptors, seem to be multifaceted processes that, apart from C1q, may affect microorganisms, apoptotic cells (Gershov et al., 2000), damaged cell membranes (Volanakis \& Wirtz, 1979), phagocytic cells (Ballou \& Lozanski, 1992), smooth muscle cells (Hattori et al., 2003), endothelial progenitor cells (Verma et al., 2004a) and endothelial cells (Pasceri et al., 2000), thereby modulating the inflammatory response.

\footnotetext{
$\triangle$ Corresponding author: Cezary Watała, Department of Hemostasis and Hemostatic Disorders, Medical University of Lodz, Medical University Hospital No. 2, Żeromskiego 113, 90-549 Łódź, Poland; tel.: (48) 42 639 3471, fax: (48) 42678 7567; e-mail: cwatala@csk.umed.lodz.pl

Abbreviations: ANG II, angiotensin II; AT1R, angiotensin type 1 receptor; BAECs, bovine aortic endothelial cells; Clq, complement pathway component; CRP, C-reactive protein; EPCs, endothelial progenitor cells; ET-1, endothelin-1; HAECs, human aortic endothelial cells; HCAECs, human coronary artery endothelial cells; HUVECs, human umbilical vein endothelial cells; ICAM-1, intercellular adhesion molecule-1; I $\kappa$ B, inhibitor of NF- $\kappa$ B; IL-1, interleukin 1; IL-6, interleukin 6; IL-8, interleukin 8; LOX-1, lectin-like oxidized LDL receptor-1; LPS, lipopolysaccharide; MCP-1, monocyte chemoattractant protein-1; NF- $\kappa$ B, transcription nuclear factor kappa B; eNOS, endothelial nitric oxide synthase; PAI-1, plasminogen activator inhibitor 1 ; $\mathrm{PCh}$, phosphocholine; $\mathrm{PEt}$, phosphoethanolamine; $\mathrm{PGI}_{2}$, prostaglandin $\mathrm{I}_{2}$; $\mathrm{PKC}$, protein kinase $\mathrm{C}$; PMA, phorbol myristate acetate; PnC, pneumococcal C-polysaccharide; SAP, serum amyloid P component; TNF, tumor necrosis factor; t-PA, tissue plasminogen activator; VCAM-1, vascular cell adhesion molecule-1; VSMCs, vascular smooth muscle cells.
} 


\section{STRUCTURE OF THE MOLECULE}

C-Reactive protein is a member of the phylogenetically highly conserved family of proteins pentraxins. The name pentraxin was first assigned to CRP due to the recognition of its ultrastructural appearance and the radial symmetry of five CRP subunits forming a pentagon ring. In general, pentraxins are characterized by a cyclic multimeric structure, calcium-dependent ligand binding, and a distinctive flattened $\beta$-jellyroll structure similar to that of the legume lectins (Emsley et al., 1994). Together with serum amyloid P component (SAP), C-reactive protein belongs to the group of short pentraxins, which differ from long pentraxins mainly by the primary structure of the subunits, gene organization, cellular source, and ligand-binding properties (Garlanda et al., 2005). Human CRP gene is localized on chromosome 1 and consists of two exons (Whitehead et al., 1983).

\section{ACUTE PHASE RESPONSE}

A native CRP molecule comprises five identical noncovalently bound subunits of 206 aa and a molecular mass of about $23 \mathrm{kDa}$ each (Osmand et al., 1977). All subunits have the same orientation in the pentamer, with a PCh binding site located on the so-called "recognition face" of each subunit. The active PCh-binding site consists of a hydrophobic pocket formed by the residues of $\mathrm{Leu}^{64}$, Phe ${ }^{66}$, and $\mathrm{Thr}^{76}$, two calcium ions, and $\mathrm{Glu}^{81}$, which is located on the other side of the hydrophobic pocket (Shrive et al., 1996). Crystallographic data on CRPPCh complexes, together with the findings on the mutational analysis of the PCh-binding site reported by Agrawal et al. (2002), clearly point out to crucial importance of $\mathrm{Phe}^{66}$ and $\mathrm{Glu}^{81}$ in mediating the binding of phosphocholine to CRP. Whereas the former provides hydrophobic interactions with methyl groups of choline, the latter interacts with the positively charged choline nitrogen. CRP complexed with C-polysaccharide, phospholipid ligands, or protamine is recognized by the complement pathway component $(\mathrm{C} 1 \mathrm{q})$ at the opposite side of the CRP pentamer ("effector face") - and thus efficiently activates the classical complement pathway. Studies on a series of CRP mutants have identified several residues that are critical for the binding of CRP to C1q (Agrawal \& Volanakis, 1994). Among them, Asp ${ }^{112}$ at the open end of the cleft, where a well-defined shallow pocket is formed - is regarded as a major determinant of $\mathrm{C} 1 \mathrm{q}$ binding to CRP complexed with PCh. Other, equally important contact sites seem to be $\mathrm{Lys}^{114}$ and $\mathrm{Tyr}^{175}$. Two mutant forms of CRP, K114A (sub- stitution of Ala for Lys ${ }^{114}$ ) and Y175A (substitution of Ala for $\mathrm{Tyr}^{175}$ ) bind PnC as avidly as the wildtype CRP but they differ in their binding to C1q. Whereas the Y175A form does not interact with human C1q, K114A binds to C1q and activates human complement many-fold better than the wild-type CRP (Agrawal \& Volanakis, 1994; Agrawal et al., 2001). It has also been shown that neither the wildtype CRP nor the CRP mutants (K114A or Y175A) interact with mouse C1q (Suresh et al., 2006). The site(s) of $\mathrm{C} 1 \mathrm{q}$ that is responsible for the interaction with CRP is poorly defined and is referred to different regions of $\mathrm{C} 1 \mathrm{q}$. This molecule can bind various activators, including IgG and/or IgM, CRP, and SAP; however, the C1q-binding sites for immunoglobulins have been mapped and attributed to the globular head region (C1qGR) (Duncan \& Winter, 1988; Perkins et al., 1991), whereas those for some other ligands were shown to be located within its collagen-like region (C1qCLR). Initially, the latter was reported to be responsible for the interaction with CRP (Jiang et al., 1991). Nevertheless, recent competition studies with the use of several mAbs directed against C1qGR or C1qCLR of human C1q have revealed that it is the globular head region of $\mathrm{C} 1 \mathrm{q}$ that is involved in the C1q-CRP interaction (McGrath et al., 2006).

\section{C-REACTIVE PROTEIN RECEPTORS}

CRP exhibits multiple functional similarities to the $G$ class of immunoglobulins (IgG), including their ability to interact with both $\mathrm{C} 1 \mathrm{q}$ and $\mathrm{F} c \gamma$ receptors (Du Clos, 2000). Whether CRP binds to these ligands at the IgG ligand-binding site is not clear. It is known that IgG subclasses with the highest affinity for the receptor have the sequence ${ }^{234}$ LLGGP, which is important for Fc $\gamma$ RI (CD64) and Fc $\gamma$ RIIa (CD32) binding. A similar sequence ${ }^{175}$ YLGGP has been found in CRP molecule, and this site has been proposed to be involved in binding to Fc $\gamma$ RI. The modification of $\mathrm{Leu}^{176}$ to Glu in CRP ( ${ }^{175}$ YEGGP-CRP) was found not to decrease CRP binding to monocytes; however, there was no binding of ${ }^{175}$ YEGGPCRP to cells transfected with the cDNA for Fc $\gamma$ RI (Marnell et al., 1995). In addition to Leu ${ }^{176}$, the residues Lys ${ }^{114}$, Thr ${ }^{173}$, and Asn ${ }^{186}$ in CRP have been indicated to be critical for binding to Fc $\gamma$ RI. Thr ${ }^{173}$ and $\mathrm{Asn}^{186}$ were important for binding to Fc $\gamma$ RIIa, and mutations of Lys ${ }^{114}$, Leu ${ }^{176}$, and $\mathrm{Thr}^{173}$ affected C1q binding as well (Bang et al., 2005). Such analysis of CRP mutants identified new important residues in $\mathrm{F} c \gamma \mathrm{R}$ and $\mathrm{C} 1 \mathrm{q}$ binding and provided the evidence that the binding sites on CRP for Fc $\gamma$ RI, Fc $\gamma$ RIIa, and $\mathrm{C} 1 \mathrm{q}$ may overlap. Other intrinsic CRP ligands include small ribonucleoprotein particles (Du Clos, 
1989), lipoproteins (Bhakdi et al., 1999; Chang et al., 2002), and extracellular matrix components (Salonen et al., 1984; Tseng \& Mortensen, 1988; Swanson et al., 1989).

\section{ISOFORMS OF C-REACTIVE PROTEIN}

Native pentameric C-reactive protein (nCRP) may undergo structural changes from pentamer to forms resembling more the free CRP subunit, designated as modified CRP (mCRP). They are distinguished from nCRP by their antigenic, electrophoretic, and biological activities (see below) (Potempa et al., 1983; 1987). Generally, mCRP can be generated from nCRP by exposing nCRP to heat, urea, or acidic conditions in the absence of calcium ions. Complete conversion of nCRP to mCRP under denaturating conditions proceeds rapidly (2 $\mathrm{min})$, but it requires high concentrations of urea (Potempa et al., 1983; Kresl et al., 1998). Moreover, direct immobilization of nCRP on polystyrene plates has been shown to produce mCRP (Potempa et al., 1983). On membranes, including those of liposomes and cells, such a structural transition of nCRP into mCRP may be a more complicated process that involves the formation of monomers that express mCRP antigenicity but retain the native pentameric conformation (originally designated by the authors as $\mathrm{mCRP}_{\mathrm{m}}$ ) (Ji et al., 2007). According to these authors, expression of the neoepitope in nCRP bound to a membrane is not necessarily associated with a physical separation of the subunits. The dissociation process may consist of the following steps: (1) nCRP binds to a membrane; (2) nCRP undergoes conformational changes on the membrane such as slight but appreciable tertiary structure alteration and neoepitope expression; (3) relaxation of nCRP oligomeric structure; and (4) physical separation of subunits. The extent of nCRP dissociation strongly depends on CRP ligand and experimental conditions. As suggested, a hydrophobic microenvironment, considerable ligand mobility (relevant to bilayer lipid fluidity), and multipoint attachment are necessary elements for efficient dissociation of nCRP. In the monomeric form, CRP retains the ability to interact with complement (Ji et al., 2006b; Biro et al., 2007). Depending on whether mCRP is in a fluid phase or is bound to a surface, there are two pathways by which mCRP may bind to $\mathrm{C} 1 \mathrm{q}$ and thus regulate complement activation. When mCRP is in the ligand-free state, it exhibits an inhibitory activity towards a complement, whereas immobilized mCRP is able to activate the classical complement pathway, thus demonstrating a dual role in the innate immune system (Ji et al., 2006b).

\section{C-REACTIVE PROTEIN SYNTHESIS}

Native CRP is synthesized in a soluble form by hepatocytes from where it is secreted into the circulation (Hurlimann et al., 1966). Interleukin 1 (IL-1), IL-6, and tumor necrosis factor (TNF) are considered important mediators for the modulation of CRP synthesis in the liver (Ganter et al., 1989; Yap et al., 1991). Induction of CRP expression in human hepatoma Hep3B cells by proinflammatory cytokines (IL6 and IL-1 $\beta$ ) may be hampered by statins or nitric oxide (NO) (Voleti \& Agrawal, 2006). Furthermore, CRP has been found in extrahepatic tissues; however, it remains unknown whether it is deposited at those sites from a circulating plasma pool or is produced locally by the cells, and what exactly is the contribution of extrahepatic CRP to its serum levels. Arterial tissue itself is able to produce CRP and complement proteins, and both the mRNAs and proteins are substantially up-regulated in atherosclerotic plaques (Yasojima et al., 2001). The first evidence for the presence of CRP in atherosclerotic lesion was revealed in immunohistochemical studies (Vlaicu et al., 1985), and experimentation along this line brings new insights into the nature of CRP. Significant levels of human CRP antigen were found in human early atherosclerotic lesions with the location in deep fibroelastic layer and fibromuscular layer of the intima adjacent to the media (Torzewski et al., 1998). At these sites, CRP is frequently colocalized with the terminal C5b-9 component complex, which supports the hypothesis of in situ CRP-mediated complement activation in the arterial wall (Torzewski et al., 1998). Unexpectedly, that conclusion became a subject of controversy since the authors had used in their study a monoclonal antibody that recognized both isoforms of CRP, the native and the modified one. Following the authors' suggestions, it is likely that nCRP may activate complement after binding to ligands (phospholipids, lipoproteins, or nuclear debris), and it may finally be transformed into mCRP under the acidic conditions of an inflammatory microenvironment. One cannot exclude that such a modification of the protein may occur at least in the course of intermediate and advanced atherosclerotic lesions (Vaith \& Potempa, 2000).

Modified CRP seems to be a naturally occurring tissue-based form of CRP in the organism, and it has been identified in both normal and pathological tissues. By probing various human tissues (pulmonary, ovarian, testicular, cardiac) with well characterized monoclonal antibodies specific for either nCRP or mCRP, it has been demonstrated that significant amounts of $\mathrm{mCRP}$ are present in the walls of blood vessels associated with normal human tissues (Diehl et al., 2000). However, normal renal tissue was found to be mCRP-negative. In 
turn, diabetic patients with severe chronic kidney disease showed progressive tubular mCRP staining with declining renal function and increasing severity of histological lesions (Schwedler et al., 2003). The natural expression of CRP in the cells involved in atherosclerotic lesion formation has also been investigated (Ciubotaru et al., 2005). CRP transcript was minimally expressed in undifferentiated macrophages (U937-derived macrophages). The expression of CRP increased markedly in macrophages during differentiation from monocytes, and it was not affected by LPS at $24 \mathrm{~h}$. Further investigation of the effect of LPS on the production of CRP protein showed that LPS time-dependently increased the production of CRP, peaking at $48 \mathrm{~h}$. After $24 \mathrm{~h}$ of LPS stimulation, macrophages had a significantly higher amount of CRP compared with unstimulated, differentiated macrophages. These findings indicate that LPS modulates CRP synthesis at the translational rather than transcriptional level, since there was no concurrent increase in the level of CRP mRNA detected in PMA-differentiated macrophages in the presence or absence of LPS stimulation. In addition, LPS-stimulated macrophages most likely produce mCRP. Other investigators reported the presence of CRP in human neuronal cells (Yasojima et al., 2000), lung epithelial cells (Ramage et al., 2004), renal cortical tubular epithelial cells (Jabs et al., 2003), and human coronary artery smooth muscle cells (Calabro et al., 2003).

\section{C-REACTIVE PROTEIN AND CARDIOVASCULAR DISEASE}

C-reactive protein is a classical acute-phase plasma protein, and its serum levels rise rapidly and markedly (even to as much as 1000-fold within $48 \mathrm{~h}$ ) in response to bacterial infection, trauma, tissue necrosis, and inflammation (Pepys, 1981; Gewurz et al., 1982). In recent years, CRP, formerly considered solely as a marker of inflammation, has been designated as a powerful independent predictor of future cardiovascular risk. A plethora of studies have demonstrated a direct association between an elevated CRP level and the incidence of cardiovascular complications in individuals without overt cardiovascular disease (Ridker et al., 2000a; 2000b), as well as in patients with unstable angina (Liuzzo et al., 1994; Biasucci et al., 1999), myocardial infarction (Ridker et al., 2003), ischemic stroke (Ridker, 2002a), or peripheral artery disease (Ridker et al., 2001). In addition, an elevated CRP concentration in blood serum predicts the risk of sudden death (Albert et al., 2002) and restenosis after percutaneous coronary intervention (Blake \& Ridker, 2002). The outcomes of the Women's Health Study suggest that determina- tion of CRP in blood may provide a valuable tool in primary prevention as it permits identifying apparently healthy subjects who are at risk of developing cardiovascular events in conjunction with an altered lipid profile (Ridker et al., 2002b). Furthermore, CRP seems to be an even stronger predictor of the risk of cardiovascular events than serum levels of LDL cholesterol. Despite the emerging evidence suggesting a proatherogenic role of CRP in atherosclerosis, the contribution of CRP in pathogenesis of atherosclerosis and atherothrombosis is not yet unequivocally defined and accepted (Nilsson, 2005; Pepys, 2005; 2008; Scirica \& Morrow, 2006). Very recently, the relationship between CRP level, several CRP polymorphisms and risk of ischaemic vascular disease has been analyzed in four large independent studies (Zacho et al., 2008). Consistent with most but not all previous studies are reports pointing out that the genetic variants associated with life-long increases in plasma CRP levels were not associated with an increased risk of ischaemic vascular disease (Kovacs et al., 2005; Wang et al., 2006; Kathiresan et al., 2006; Reitz et al., 2007; Bis et al., 2008). In the light of a concurrent observation on a significant association between CRP level and an increased risk of ischaemic heart disease and ischaemic cerebrovascular disease, such findings suggest that increased CRP level is not a cause but rather a marker for atherosclerosis (Zacho et al., 2008).

\section{IN VITRO STUDIES}

Numerous literature reports document the role of C-reactive protein in atherogenesis. Epidemiological evidence reveals an association between elevated CRP plasma levels and atherosclerosis (Haverkate et al., 1997; Ridker et al., 1997; Koenig et al., 1999). Infusion of recombinant CRP in healthy men results in the activation of inflammation and coagulation (Bisoendial et al., 2005). In vitro, CRP has been shown to exert direct proinflammatory and proatherosclerotic effects on vascular cells, as exemplified by: (1) induction of an increased expression of adhesion molecules, such as vascular cell adhesion molecule-1 (VCAM-1), intercellular adhesion molecule-1 (ICAM-1), and E-selectin (Pasceri et al., 2000); (2) stimulation of secretion of monocyte chemoattractant protein-1 (MCP-1) (Pasceri et al., 2001); and (3) facilitation of macrophage LDL uptake (Verma et al., 2002a). At present, we think that the majority of these effects are likely to be mediated, in part, by an increased secretion of the potent endothelium-derived vasoactive factor, endothelin-1 (ET-1), and the inflammatory cytokine, interleukin-6 (IL-6), because these effects are attenuated by both bosentan (mixed $\mathrm{ET}_{\mathrm{A} / \mathrm{B}}$ receptor antagonist) and monoclonal anti-hu- 
man IL-6 antibodies (Verma et al., 2002a). C-Reactive protein-induced endothelial dysfunction may also be mediated by a major receptor for ox-LDL, the endothelial lectin-like oxidized LDL receptor-1 (LOX-1). Incubation of human aortic endothelial cells (HAECs) with CRP leads to enhanced synthesis of LOX-1 mRNA and protein, and the observed changes become attenuated in the presence of anti-ET-1 or IL-6 antibodies, thus supporting the above concept on the association between the stimulated ET-1 and IL-6 production and biological effects of CRP ( $\mathrm{Li}$ et al., 2004).

The conformation of the CRP molecule seems to be of crucial importance for triggering of the release of key regulators of leukocyte recruitment and expression of adhesion molecules in endothelial cells. Khreiss et al. (2004a) have demonstrated that modified CRP has a proinflammatory effect on human coronary artery endothelial cells (HCAECs) by increasing MCP-1 and IL- 8 secretion and by inducing the cellular expressions of ICAM-1, VCAM-1, and Eselectin following a 4-hour incubation with the protein. Otherwise, the contribution of native CRP in the development of vascular inflammation has been suggested to be a minor one: native CRP was not able to promote proinflammatory HCAEC phenotype until the incubation time was prolonged from $4 \mathrm{~h}$ to $24 \mathrm{~h}$. In studies on platelet adhesion to bovine aortic endothelial cells (BAECs), the pro-adhesive effect of CRP was also time-dependent, requiring at least $7 \mathrm{~h}$ of incubation (Yaron et al., 2006). This remains fairly consistent with previous studies pointing to a pro-adhesive action of nCRP merely after 6$12 \mathrm{~h}$ of incubation with endothelium, with the maximal effects at $24 \mathrm{~h}$ (Pasceri et al., 2000; 2001; Verma et al., 2002a). Interestingly, these findings coincide very well with the outcome of in vitro studies on the kinetics of CRP dissociation into subunits (Wang \& Sui, 2001). In another comparative analysis of CRP conformers, the native CRP isoform was even more potent than modified CRP as the modulator of IL8, PAI-1, cGMP, and prostaglandin F1- $\alpha$ levels after $6 \mathrm{~h}$ of incubation with HAECs (Devaraj et al., 2006). It is worth mentioning that the origin or type of endothelial cells might also be critical for the outcome of the study. For instance, Devaraj et al. (2004) failed to observe a stimulatory effect of CRP on MCP-1 release in HAECs, while such an effect was claimed in experiments with human umbilical vein endothelial cells (HUVECs) (Pasceri et al., 2001).

C-Reactive protein also has the ability to modulate directly the production of endotheliumderived vasoactive factors. It is able to profoundly down-regulate the expression and bioactivity of endothelial nitric oxide synthase (eNOS) (Venugopal et al., 2002), NO production (Verma et al., $2002 \mathrm{~b}$ ), and prostacyclin $\left(\mathrm{PGI}_{2}\right)$ release (Venugopal et al., 2003). The ability of CRP to attenuate NO release is associated with a markedly suppressed in vitro angiogenesis and promotion of endothelial cell apoptosis (Verma et al., 2002b). Further, interactions between C-reactive protein and endothelium may lead to impaired fibrinolysis. Incubation of HAECs with CRP results in a time- and dosedependent increase in the antigen concentration and activity of secreted PAI-1, as well as elevated concentrations of intracellular PAI-1 protein and mRNA (Devaraj et al., 2003). These alterations, however, are mediated by neither ET-1 nor IL-6. Concomitantly, CRP treatment reduces antigen levels and activity of secreted t-PA and downregulates intracellular concentrations of t-PA. Such an inhibition seems to be mediated by the generation of proinflammatory cytokines, like IL-1 $\beta$ and TNF $\alpha$ (Singh et al., 2005).

The direct proatherogenic effects of CRP extend beyond the endothelium and concern also vascular smooth muscle cells (VSMCs), where it activates angiotensin-1 type receptors (Wang et al., 2003). The primary effector molecule of the renninangiotensin system (RAS), angiotensin II (ANG II), has emerged as a critical hormone that affects the function of virtually all organs, including heart, kidney, vasculature, and brain, showing both beneficial and pathological effects. Most of the known physiological effects of angiotensin II are mediated by angiotensin type 1 receptors (AT1Rs). Once ANG II binds to the AT1R, it activates a series of signaling cascades, which in turn regulate the function of VSMCs, endothelial cells, and cardiac fibroblasts, as well as influence their interaction with the extracellular matrix. Convergence of these cascades of events, in addition to abnormalities in the coagulation system, ultimately lead to atherosclerosis and thrombosis with the development of cardiovascular disease (Mehta \& Griendling, 2007). The experiments on VSMCs have shown that CRP potently up-regulates AT1R mRNA and protein and increases the number of the binding sites for angiotensin II on the cell surface. Secondly, CRP markedly promoted VSMC migration/proliferation and increased basal reactive oxygen species (ROS) production. Additionally, it potentiated the effects of ANG II on these processes (Wang et al., 2003). In line with those findings, the detrimental CRP-mediated effects have also been observed in bone marrow-derived endothelial progenitor cells (EPCs), which are responsible for vascular regenerative potential and integrity (Suh et al., 2004; Verma et al., 2004a). The number and migratory activity of circulating EPCs have also been shown to inversely correlate with cardiovascular risk (Shantsila et al., 2007). Thus, the ability of CRP to inhibit EPC differentiation and survival may represent an impor- 
tant mechanism that further links inflammation to cardiovascular disease (Verma et al., 2004a).

During inflammation, the transendothelial migration of leukocytes is controlled by chemotactic and activating signals, together with the sequential interaction between adhesion molecules and their corresponding ligands. C-reactive protein seems to play an important role in these events. To date, experiments with monocytes have shown that CRP induces the production of inflammatory cytokines (IL1, IL-6, TNF $\alpha$, IL-8) (Ballou \& Lozanski, 1992; Xie et al., 2005), generation of reactive oxygen species (Zeller \& Sullivan, 1992), leads to increased expression of tissue factor (Cermak et al., 1993), and affects cell chemotaxis (Whisler et al., 1986; Kew et al., 1990). Very recently, Hanriot et al. (2008), investigating human monocytes exposed to CRP have confirmed the results of earlier studies on CRP-mediated induction of expression of numerous proinflammatory cytokine genes (with the exception of TNF $\alpha$ ) and further evidenced increased expression of mRNA for PAI-2, MCP-1, GRO- $\alpha$, GRO- $\beta$, and the chemokine receptors CCR8 and CXCR4. Upon CRP stimulation, monocytic cells have also been shown to up-regulate their vascular endothelial growth factor A (VEGF-A) expression and, to some extent, de novo protein synthesis. Thus, by favoring the activation of endothelial and smooth muscle cells, CRP has been confirmed to promote angiogenesis (Bello et al., 2008). Simultaneously, CRP has been reported to display anti-inflammatory effects in monocytes through down-regulation of $\alpha_{2}$-macroglobulin expression and up-regulation of liver $\mathrm{X}$ receptor (LXR) $\alpha$ expression (Hanriot et al., 2008). Such opposing results may be explained by the existence of as yet unidentified pathways activated by CRP in human monocytes and suggest a much more complex biological role of CRP than previously thought.

C-Reactive protein may be an important mediator of leukocyte behavior (activation and adhesion to endothelial cells) in the vasculature through the modulation of monocyte surface antigens. It has been demonstrated that CRP (both isolated from serum and recombinant) can stimulate expression of the monocytic surface integrin $\mathrm{CD} 11 \mathrm{~b}$ and downregulate that of CD31 antigen (Woollard et al., 2002). In addition, by up-regulating CD11b/CD18 expression and stimulating neutrophil extracellular signalregulated kinase (ERK) activity, the monomeric CRP (but not nCRP) may participate in the promotion of neutrophil adhesion to HCAECs (Zouki et al., 2001).

Up-regulation of adhesion molecules and cytokines by CRP appears to be at the transcriptional level. Transcription of genes encoding the cell adhesion molecules (VCAM-1, ICAM-1, E-selectin) and chemokines is tightly regulated by the transcription factor NF- $\mathrm{KB}$, which has been implicated as a key mediator of atherosclerosis (Brand et al., 1996; Marumo et al., 1997; Thurberg \& Collins, 1998; De Martin et al., 2000). This transcription factor is a DNA-binding protein complex that is usually present in the cytosol as an inactive complex. I $\kappa \mathrm{B}$, an associated protein, renders this complex inactive by shielding the nuclear localization signal. Upon IкB phosphorylation and subsequent degradation, the heterodimeric NF- $\kappa \mathrm{B}$ complex translocates from the cytoplasm to the nucleus, where it binds to specific DNA sequences in the promotor region of several genes and up-regulates their transcription. Verma et al. (2003) demonstrated for the first time that Creactive protein directly increased the degradation of I $\kappa \mathrm{B}$ and subsequently activated the NF- $\kappa \mathrm{B}$ signal transduction pathway in saphenous vein endothelial cells. This mechanism has been confirmed by others in studies on the effect of CRP on VCAM-1, IL-8, or MCP-1 expressions. CRP significantly increased IL-8 synthesis in HAECs by the enhancement of NF- $\mathrm{BB}$ activity, and such an up-regulation of IL-8 was reversed in the presence of NF- $\kappa B$ inhibitors, like SN-50, parthenolide, or Bay 11 (Devaraj et al., 2004). A significant reduction of IL-8 production by mCRP following the blockade of NF- $\kappa \mathrm{B}$ or NO synthesis has also been observed in human neutrophils (Khreiss et al., $2002 b)$. Stimulation of IL-8 production by mCRP in neutrophils was associated with simultaneously increased superoxide production and NO formation leading to enhanced $\mathrm{ONOO}^{-}$formation and consequently activation of NF- $\kappa \mathrm{B}$ and activator protein1 (AP-1). In human mesangial cells, CRP has been found to induce MCP-1 expression via NF- $\kappa \mathrm{B}$ activation mediated, at least in part, by intracellular calcium and reactive oxygen species (Chang et al., 2005). In turn, the NF-kB-dependent VCAM-1 expression induced by CRP in BAECs involves PKC, p38MAPK, and tyrosine kinase (Kawanami et al., 2006). Altogether, CRP appears to exert a wide spectrum of activities in vascular tissues that may promote progression of atherosclerosis.

The majority of reports describe the function of pentameric CRP, but only a few of them differentiate the possible effects of native CRP from those of modified CRP. It has been shown that C-reactive protein may interact with various lipoproteins (native, oxidized, or enzymatically modified) primarily when CRP is in a modified form and not the pentameric structure (Ji et al., 2006a). The mechanism of CRP-LDL interaction involves PCh-binding sites of CRP and the moieties on the LDL molecule such as apoB, cholesterol and PCh (Saxena et al., 1987; Nunomura \& Hatakeyama, 1990; Bhakdi et al., 1999; Chang et al., 2002; Taskinen et al., 2002; van Tits et al., 2005). What seems surprising is that the blocking of the PCh-binding sites of CRP with phosphoethanolamine (PEt) may change the LDL-binding affinity 
of CRP. The binding of PEt-complexed CRP to enzymatically-modified LDL (E-LDL) was enhanced over that of uncomplexed CRP (Singh et al., 2008a). Furthermore, PEt-complexed CRP bound native LDL in whole serum (Singh et al., 2008b). The mechanism of PEt action on CRP remains unknown but it is possible that PEt might induce the formation of CRP aggregates, which are able to bind native LDL in vivo and thus prevent the development of atherosclerosis (Singh et al., 2008b; 2008c). The interaction of CRP with lipoproteins may contribute to the regulation of LDL metabolism and foam cell formation in the arterial wall. As suggested, under normal conditions mCRP may exert its protective role via facilitating the safe clearance of retained native LDL from extracellular space, and thus lower the risk of formation of atherogenic LDL derivatives (e.g., ox-LDL). Under pathological conditions, mCRP can contribute to retardation of foam cell formation by reducing macrophage response to ox-LDL (Ji et al., 2006a). Recent findings also showed that CRP in its monomeric, but not native pentameric conformation, has the ability to bind a variety of immunoglobulins and other proteins (Boguslawski et al., 2007).

With regard to the blood or vascular cells, native CRP displays anti-inflammatory activity, whereas modified CRP exerts proinflammatory effects on shear-induced platelet adherence to neutrophils and neutrophil aggregation (Khreiss et al., 2004b), neutrophil-endothelial cell adhesion (Zouki et al., 2001), neutrophil survival (Khreiss et al., 2002a), and endothelium phenotype (Khreiss et al., 2004a). The regulation of cell function by CRP is due to CRP binding to and activation of several Fc receptors on human leukocytes and endothelial cells. CRP binding to the high affinity IgG receptor Fc $\gamma$ RI (CD64) was first suggested by Muller and Fehr (1986), when it was shown that the binding of the protein to monocytic cells could be partially inhibited by monomeric IgG, and this finding was further supported by showing that the transfection of COS-7 cells with Fc $\gamma$ RI increased CRP binding (Marnell et al., 1995). In the opinion of some authors (Bharadwaj et al., 1999; Stein et al., 2000), the low affinity IgG receptor Fc $\gamma$ RIIa (CD32) is the major receptor for CRP on leukocytes, although the interpretation of data has been questioned by others (Saeland et al., 2001). As endothelium is regarded, CRP has been shown to bind mainly to CD32, but also to CD64 on HAECs (Devaraj et al., 2005). Preincubation with anti-CD32 or anti-CD64 antibodies inhibited maximal binding of CRP to HAECs, by $64 \%$ and $30 \%$, respectively, whereas antibodies directed against Fc $\gamma$ RIIIb (antiCD16) had no effect. In line with those findings are functional studies on the effects of CRP isoforms on neutrophil function, which have revealed distinct $\mathrm{Fc} \gamma$ receptors for native and modified CRP on leukocytes. Unlike the native isoform, the modified CRP can bind with a low affinity to Fc $\gamma$ RIIIb (CD16), thus inhibiting neutrophil chemotaxis (Heuertz et al., 2005). Native CRP is also able to induce the same effect, but the mechanism of nCRP interaction with neutrophils is distinct from that of mCRP since, for instance, the binding of human or rabbit native CRP was not affected by the presence of antiCD16 antibody (Heuertz et al., 2005). Earlier reports have already described the involvement of distinct $\mathrm{F} c \gamma$ receptors in the modulation of neutrophil function by various CRP isoforms. Moreover, some authors suggest even the opposite roles for native and mCRP in adhesion of neutrophils to HCAECs (Zouki et al., 2001), or platelets (Khreiss et al., 2004b) and neutrophil survival (Khreiss et al., 2002a). It has been proposed that the binding of nCRP to Fc $\gamma \mathrm{RI}$ and/or Fc $\gamma$ RIIa is associated with shedding of L-selectin without neutrophil activation and the subsequent attenuation of polymorphonuclear leukocytes (PMN) adhesion to activated endothelial cells. In turn, when pentameric CRP is dissociated into its monomeric subunits, their binding to neutrophils is mediated via Fc $\gamma$ RIIIb and results in an increased adhesion of PMNs to activated endothelium (Zouki et al., 2001). Again, the incubation of neutrophils with $\mathrm{mCRP}$, but not $\mathrm{nCRP}$, gives rise to delayed neutrophil apoptosis (Khreiss et al., 2002a). Some observations point that modified CRP can inhibit the development of morphologic features characteristic for apoptosis, as well as DNA fragmentation in the cells, and reduce the percentage of annexin V-positive neutrophils. The prolongation of neutrophil survival by $\mathrm{mCRP}$ is thought to be in part mediated by Fc $\gamma$ RIIIb through stimulation of the PI 3-kinase/Akt and MEK/ERK signaling pathways, finally leading to inhibition of caspase-3, one of the key effectors of apoptosis (Khreiss et al., 2002a).

In addition to classical neutrophil recruitment into the inflamed endothelium, platelets bound to activated endothelial cells can interact with leukocytes, thus providing an indirect mechanism of neutrophil-endothelial interaction (Mine et al., 2001). Neutrophil rolling on platelets is modeled as a multiple-step process which involves initial tethering (mostly mediated by platelet P-selectin binding to P-selectin glycoprotein ligand-1 (PSGL-1) on leukocytes) followed by firm adhesion achieved by CD11b/CD18 (Mac-1) binding to GPIb $\alpha$ (Simon et al., 2000) and/or junctional adhesion molecule 3 (JAM-3) (Santoso et al., 2002). In studies on the effects of CRP conformers on the interplay between platelets and neutrophils, it has been found that modified CRP, in contrast to nCRP, may accelerate shear-induced platelet-neutrophil adhesion and neutrophil aggregation (Khreiss et al., 2004b). A complete abrogation of platelet-neutrophil adhesion and neutrophil 
aggregation required both anti-P-selectin and antiCD18 antibodies, thus indicating the possible role of P-selectin and Mac-1 in the enhancement of adhesive interactions by mCRP. The observed functional antagonism between CRP isoforms in regulation of platelet P-selectin expression is also consistent with their action on platelet reactivity in response to various agonists (Fiedel \& Gewurz, 1976a, 1976b; Fiedel et al., 1977, 1982; Boncler et al., 2006).

Although the studies that evaluated the $\mathrm{nCRP} / \mathrm{mCRP}$ functional differences have provided rather consistent results, they are limited by the fact that merely the recombinant form of mCRP $\left(\mathrm{r}_{\mathrm{m}}-\mathrm{CRP}\right)$, and not native modified CRP isolated from biological material $\left(\mathrm{b}_{\mathrm{m}}-\mathrm{CRP}\right)$ was used in the majority of those experiments. The recombinant and biological mCRP differ slightly in primary structure: $r_{m}$-CRP compared to $b_{m}$-CRP has two alanines instead of cysteine residues at positions 36 and 97, and an additional N-terminal formylmethionine residue. Besides, to enhance its solubility, $\mathrm{r}_{\mathrm{m}}$-CRP is subjected to acylation (Khreiss et al., 2002a). These differences notwithstanding, these two mCRP forms showed high similarity in terms of biochemical characteristics, i.e., SDS/PAGE size, solubility, and antigenicity. With respect to in vitro activities, the effects of recombinant and biological mCRP on blood cells have not been extensively examined. Preliminary data published by Khreiss and coworkers (2002a), revealed a similar effect of $r_{m}$ $\mathrm{CRP}$ and $\mathrm{b}_{\mathrm{m}}$-CRP in delaying neutrophil apoptosis.

\section{ANIMAL MODELS}

First reports comparing the activities of CRP isoforms in animals appeared at the end of the previous century, when CRP was considered a therapeutically effective agent. Then, modified CRP, in contrast to native human CRP, was demonstrated to have a stimulatory effect on in vitro and in vivo murine thrombopoiesis (Potempa et al., 1996). In addition, in a murine model of mammary adenocarcinoma, it was shown that mCRP also has anticancer and antimetastatic activity, since the treatment with mCRP led to the inhibition of tumor growth and metastasis in mice (Kresl et al., 1999).

The most broadly available animal model, the mice, is considered largely useless regarding the study of CRP functions, because CRP is not an acute phase component in mice. To overcome this problem, a model of transgenic mice expressing human CRP (CRPtg mice) has been utilized to study the biological activities of human CRP in vivo. Unlike human CRP, mouse CRP circulates only in trace amounts, and its blood level does not change appreciably during inflammation (Szalai \& McCrory,
2002). Furthermore, male CRPtg mice constitutively produce human CRP with serum levels that are considered to indicate high risk in humans. However, foreign antigenicity of human CRP in tissues of mice, despite their high homology (murine CRP shares $70 \%$ homology with human CRP), as well as the inability of human CRP to activate the complement pathway in mice, claimed by some authors studying effects of human CRP in mice, are regarded as serious limitations of the system and a possible source of contradictory results (Suresh et al., 2006). Even the most widely used apolipoprotein E knockout $\left(\mathrm{ApoE}^{-/-}\right)$mouse model of atherosclerosis has been disapproved due to a not fully functional complement system in apoE-deficient mice (Reifenberg et al., 2005; Torzewski, 2005). With the use of wild type and human CRP-transgenic mice, Danenberg et al. (2003) described the first in vivo experiments of vascular injury, which clearly demonstrated a significantly faster and higher rate of arterial thrombosis in CRP-transgenic mice, thus pointing to a cause-effect relationship between CRP and thrombotic events. In addition, the influence of human CRP on monocyte-platelet aggregates (MPA) formation in CRPtg mice was examined (Danenberg et al., 2007). Following LPS injection, MPA levels were increased in CRPtg mice compared to wild-type mice, although no overt thromboses were observed. Transgenic expression of human CRP in apoE-deficient mice has been reported to accelerate (Paul et al., 2004), slow (Kovacs et al., 2007), or have no effect on atherosclerosis (Hirschfield et al., 2005; Trion et al., 2005; Tennent et al., 2008). The apoE-deficient transgenic mice have also been used to compare the effects of human nCRP and mCRP on the development of early atherosclerosis by using directly injected proteins (Schwedler et al., 2005). Those results evidently indicate that the configuration of CRP may determine differential effects on atherosclerosis in mice, as it does in humans. Native CRP enhanced plaque formation in apo: $\mathrm{E}^{-/-}$mice with early lesions, while mCRP reduced plaque formation and increased serum levels of the anti-inflammatory cytokine IL-10. Using the identical treatment protocols, those authors have also revealed that nCRP, but not mCRP, may impair endothelial function in aortic rings, which can in part be due to an increased activity of iNOS and peroxynitrite formation (Schwedler et al., 2007). In line with those findings is the paper by Bisoendial et al. (2007) showing a deteriorated endothelium-dependent vasodilator capacity and enhanced procoagulant response upon CRP challenge in patients with familial hypercholesterolemia compared to normolipidemic subjects. The pathophysiological significance of C-reactive protein in atherosclerosis has also been demonstrated in hypercholesterolemic rabbits. In comparison with 
normal rabbits, both cholesterol-fed and Watanabe heritable hyperlipidemic (WHHL) rabbits had significantly elevated CRP levels, and CRP concentration strongly correlated with the extent of atherosclerotic lesions in these animals (Sun et al., 2005). Taken together, the discrepancy in the outcomes of the animal studies does not allow definitive confirmation of the contribution of CRP in human atherogenesis. The development of a specific anti-CRP therapy, involving CRP inhibitors, would help in resolving this question.

\section{CONTAMINATIONS IN CRP PREPARATIONS}

The most commonly used commercially available preparations of CRP are recombinant CRP materials that most often contain a lot of contaminants, including bacterial lipopolysaccharide (LPS) and the preservative, sodium azide $\left(\mathrm{NaN}_{3}\right)$. Several studies have systematically evaluated the impact of different preparations of CRP on a variety of cell lines to determine whether inflammatory reactions are due more to CRP or to the contaminant. Van den Berg and coworkers (2004) have investigated the influence of three various CRP preparations (two azidefree CRP preparations, in-house recombinant CRP and ascites-derived CRP, versus commercial CRP) on vascular smooth muscle cell relaxation. They found that only the commercial CRP was able to induce vasorelaxation, which was further elucidated to be caused by the sodium azide present in this preparation and not by CRP itself. This data has been confirmed and extended by Swafford and coworkers (2005), who demonstrated no effect of CRP on regulation of vascular tone and proved that $\mathrm{NaN}_{3}$, as a source of NO, may induce vasodilatation, which is likely mediated by the cGMP-dependent activation of smooth muscle $\mathrm{K}^{+}$channels. In another series of experiments, changes in endothelial cell function (i.e., proliferation, morphology, apoptosis, expression of eNOS and ICAM-1, and levels of MCP-1, IL-8, or von Willebrand factor) in the presence of various CRP preparations, LPS, or azide have been monitored (Taylor et al., 2005). In accordance with previous observations (van den Berg et al., 2004), none of the reported effects of CRP on endothelial cells could be ascribed to CRP, but rather to the contaminants. The possible contribution of other non-CRP components of the solution, particularly sodium azide, has been analyzed with respect to the influence of CRP on proinflammatory mechanisms evoked by IL-1 $\beta$ in cultured human vascular smooth muscle cells. Again, sodium azide, similarly to commercial CRP and vehicle medium, attenuated the induction of iNOS and NO release in this cell type. When sodium azide was removed from the CRP solution or the vehicle medium by dialysis, the previously observed effects were almost lost, which argued for sodium azide as the main mediator of such effects (Lafuente et al., 2005). The action of different CRP preparations - commercial recombinant CRP and human CRP purified from malignant ascitic fluid - were also tested in vivo. Intravenous injection into mice of malignant ascites-derived CRP did not induce an acute phase response of either mouse SAP or SAA. In contrast, injection of CRP from a commercial bacterial recombinant preparation induced a dramatic increase in the circulating concentration of both these proteins, compatible with the well known exquisitely sensitive murine acute phase response to endotoxin (Pepys et al., 2005). The recombinant material also triggered an inflammatory marker, $\mathrm{TNF} \alpha$, and signaling responses in mouse macrophages in vitro, whereas non-recombinant CRP did not, again suggesting that a contaminant of the commercial preparation is a probable cause of the inflammatory stimulation rather than CRP itself. That view, however, is not shared by all researchers, who showed that the biological effects of CRP on endothelium are specific to the protein and not related to contamination with either endotoxin or azide and occur at concentrations observed in patients to predict future vascular events (Verma et al., 2006; Dasu et al., 2007).

In summary, it seems reasonable to use in experiments the most pure preparation of CRP available; otherwise, adequate controls (including control buffers, control proteins, antibodies, blockers) are obligatory to minimize artifactual observations. On the other hand, the homogeneity of CRP preparations is equally important. For example, storage in the absence of calcium, complexed with cell membranes, or in a plastic container may lead to the formation of mCRP. In addition, prolonged storage is known to cause relaxation in the pentameric structure of CRP, which makes it more susceptible to the conversion into mCRP (Ji et al., 2006a).

\section{FUTURE PERSPECTIVES AND CONCLUDING REMARKS}

The role of CRP in pathophysiology/pathology has rarely been discussed with the reference to its structural heterogeneity. In the majority of papers CRP is considered a "villain", without even mentioning which form of this protein, pentameric or monomeric, we talk about. Some researchers may consider this fact justified, as far as there is no reliable commercial assays to well distinguish between the various biological forms of CRP. The available diagnostic methods enable determination of the whole pooled population of CRP molecules in the 
blood, which is of course an excessive simplification that may occasionally lead to inconsistencies in clinical reports. Regardless of these limitations, we have to remain aware that the biological (and evolutionary) roles of the native (pentameric) and modified (monomeric) forms of CRP are to a large extent opposite. Ignoring this fact may easily lead to accumulation of artefactual findings and/or detecting spurious relationships between CRP concentrations and its tentative biological effects.

Despite some methodological problems reported in the studies on CRP isoforms, there is accumulating evidence on the importance of pentameric and monomeric CRP in both the innate immune system and atherogenesis. Further investigations related to the development of a specific anti-CRP therapy are needed to definitely verify a direct pathogenic role of CRP and to better understand the role of CRP conformers in physiology and atherosclerotic lesion formation. It has been speculated that inhibition of CRP may be achieved with agents that directly affect CRP synthesis, action (transcriptional inhibition of CRP synthesis, antisense therapy, blockade of CRP-mediated complement activation, blockade of CRP receptors) (Scirica \& Morrow, 2006) or influence CRP structure (conversion between pentameric and monomeric CRP forms, destabilization of CRP monomers) (Verma et al., 2004b). The first therapeutic inhibition of CRP with 1,6-bis(phosphocholine)hexane has been shown to be a promising approach to cardioprotection in rats (Pepys et al., 2006). Further studies with the use of anti-CRP agents should resolve the questions of the association between CRP and atherosclerosis and cardiovascular risk.

\section{Acknowledgements}

This work was supported by grants from the Ministry of Science and Higher Education (N N401 213934) and Medical University of Lodz (502-16814).

\section{REFERENCES}

Agrawal A, Shrive AK, Greenhough TJ, Volanakis JE (2001) Topology and structure of the C1q-binding site on C-reactive protein. J Immunol 166: 3998-4004.

Agrawal A, Simpson MJ, Black S, Carey MP, Samols D (2002) A C-reactive protein mutant that does not bind to phosphocholine and pneumococcal C-polysaccharide. J Immunol 169: 3217-3222.

Agrawal A, Volanakis JE (1994) Probing the C1q-binding site on human C-reactive protein by site-directed mutagenesis. J Immunol 152: 5404-5410.

Albert CM, Ma J, Rifai N, Stampfer MJ, Ridker PM (2002) Prospective study of C-reactive protein, homocysteine, and plasma lipid levels as predictors of sudden cardiac death. Circulation 105: 2595-2599.
Ballou SP, Lozanski G (1992) Induction of inflammatory cytokine release from cultured human monocytes by C-reactive protein. Cytokine 4: 361-368.

Bang R, Marnell L, Mold C, Stein MP, Clos KT, Chivington-Buck C, Clos TW (2005) Analysis of binding sites in human C-reactive protein for Fc $\gamma$ RI, Fc $\gamma$ RIIA, and $\mathrm{C} 1 \mathrm{q}$ by site-directed mutagenesis. J Biol Chem 280: 25095-25102.

Bello G, Cailotto F, Hanriot D, Kolopp-Sarda MN, LatgerCannard V, Hess K, Zannad F, Longrois D, Ropars A (2008) C-reactive protein (CRP) increases VEGF-A expression in monocytic cells via a PI3-kinase and ERK 1/2 signaling dependent pathway. Atherosclerosis 200: 286-293.

Bhakdi S, Torzewski M, Klouche M, Hemmes M (1999) Complement and atherogenesis: binding of CRP to degraded, nonoxidized LDL enhances complement activation. Arterioscler Thromb Vasc Biol 19: 2348-2354.

Bharadwaj D, Stein MP, Volzer M, Mold C, Du Clos TW (1999) The major receptor for C-reactive protein on leukocytes is Fc $\gamma$ receptor II. J Exp Med 190: 585-590.

Biasucci LM, Liuzzo G, Grillo RL, Caligiuri G, Rebuzzi AG, Buffon A, Summaria F, Ginnetti F, Fadda G, Maseri A (1999) Elevated levels of C-reactive protein at discharge in patients with unstable angina predict recurrent instability. Circulation 99: 855-860.

Biro A, Rovo Z, Papp D, Cervenak L, Varga L, Fust G, Thielens NM, Arlaud GJ, Prohaszka Z (2007) Studies on the interactions between $C$-reactive protein and complement proteins. Immunology 121: 40-50.

Bis JC, Heckbert SR, Smith NL, Reiner AP, Rice K, Lumley T, Hindorff LA, Marciante KD, Enquobahrie DA, Monks SA, Psaty BM (2008) Variation in inflammation-related genes and risk of incident nonfatal myocardial infarction or ischemic stroke. Atherosclerosis 198: 166-173.

Bisoendial RJ, Kastelein JJ, Levels JH, Zwaginga JJ, van den BB, Reitsma PH, Meijers JC, Hartman D, Levi M, Stroes ES (2005) Activation of inflammation and coagulation after infusion of C-reactive protein in humans. Circ Res 96: 714-716.

Bisoendial RJ, Kastelein JJ, Peters SL, Levels JH, Birjmohun R, Rotmans JI, Hartman D, Meijers JC, Levi M, Stroes ES (2007) Effects of CRP infusion on endothelial function and coagulation in normocholesterolemic and hypercholesterolemic subjects. J Lipid Res 48: 952-960.

Blake GJ, Ridker PM (2002) C-reactive protein and prognosis after percutaneous coronary intervention. Eur Heart J 23: 923-925.

Boguslawski G, McGlynn PW, Potempa LA, Filep JG, Labarrere CA (2007) Conduct unbecoming: C-reactive protein interactions with a broad range of protein molecules. J Heart Lung Transplant 26: 705-713.

Boncler M, Luzak B, Rozalski M, Golanski J, Rychlik B, Watala C (2006) Acetylsalicylic acid is compunding to antiplatelet effect of C-reactive protein. Thromb Res 119: 209-216.

Brand K, Page S, Rogler G, Bartsch A, Brandl R, Knuechel R, Page M, Kaltschmidt C, Baeuerle PA, Neumeier D (1996) Activated transcription factor nuclear factor-kappa B is present in the atherosclerotic lesion. J Clin Invest 97: 1715-1722.

Calabro P, Willerson JT, Yeh ET (2003) Inflammatory cytokines stimulated C-reactive protein production by human coronary artery smooth muscle cells. Circulation 108: $1930-1932$.

Cermak J, Key NS, Bach RR, Balla J, Jacob HS, Vercellotti GM (1993) C-reactive protein induces human periph- 
eral blood monocytes to synthesize tissue factor. Blood 82: 513-520.

Chang MK, Binder CJ, Torzewski M, Witztum JL (2002) C-reactive protein binds to both oxidized LDL and apoptotic cells through recognition of a common ligand: Phosphorylcholine of oxidized phospholipids. Proc Natl Acad Sci USA 99: 13043-13048.

Chang JW, Kim CS, Kim SB, Park SK, Park JS, Lee SK (2005) C-reactive protein induces NF- $\kappa B$ activation through intracellular calcium and ROS in human mesangial cells. Nephron Exp Nephrol 101: e165-e172.

Ciubotaru I, Potempa LA, Wander RC (2005) Production of modified C-reactive protein in U937-derived macrophages. Exp Biol Med (Maywood) 230: 762-770.

Danenberg HD, Szalai AJ, Swaminathan RV, Peng L, Chen Z, Seifert P, Fay WP, Simon DI, Edelman ER (2003) Increased thrombosis after arterial injury in human C-reactive protein-transgenic mice. Circulation 108: 512-515.

Danenberg HD, Kantak N, Grad E, Swaminathan RV, Lotan C, Edelman ER (2007) C-reactive protein promotes monocyte-platelet aggregation: an additional link to the inflammatory-thrombotic intricacy. Eur J Haematol 78: 246-252.

Dasu MR, Devaraj S, Du Clos TW, Jialal I (2007) The biological effects of CRP are not attributable to endotoxin contamination: evidence from TLR4 knockdown human aortic endothelial cells. J Lipid Res 48: 509-512.

De Martin R, Hoeth M, Hofer-Warbinek R, Schmid JA (2000) The transcription factor NF- $\mathrm{KB}$ and the regulation of vascular cell function. Arterioscler Thromb Vasc Biol 20: E83-E88.

Devaraj S, Xu DY, Jialal I (2003) C-reactive protein increases plasminogen activator inhibitor-1 expression and activity in human aortic endothelial cells: implications for the metabolic syndrome and atherothrombosis. Circulation 107: 398-404.

Devaraj S, Kumaresan PR, Jialal I (2004) Effect of C-reactive protein on chemokine expression in human aortic endothelial cells. J Mol Cell Cardiol 36: 405-410.

Devaraj S, Du Clos TW, Jialal I (2005) Binding and internalization of C-reactive protein by Fcgamma receptors on human aortic endothelial cells mediates biological effects. Arterioscler Thromb Vasc Biol 25: 1359-1363.

Devaraj S, Venugopal S, Jialal I (2006) Native pentameric C-reactive protein displays more potent pro-atherogenic activities in human aortic endothelial cells than modified C-reactive protein. Atherosclerosis 184: 48-52.

Diehl EE, Haines GK III, Radosevich JA, Potempa LA (2000) Immunohistochemical localization of modified C-reactive protein antigen in normal vascular tissue. Am J Med Sci 319: 79-83.

Du Clos TW (1989) C-reactive protein reacts with the U1 small nuclear ribonucleoprotein. J Immunol 143: 25532559.

Du Clos TW (2000) Function of C-reactive protein. Ann Med 32: 274-278.

Duncan AR, Winter G (1988) The binding site for C1q on IgG. Nature 332: 738-740.

Emsley J, White HE, O'Hara BP, Oliva G, Srinivasan N, Tickle IJ, Blundell TL, Pepys MB, Wood SP (1994) Structure of pentameric human serum amyloid P component. Nature 367: 338-345.

Fiedel BA, Gewurz H (1976a) Effects of C-reactive protein on platelet function. I. Inhibition of platelet aggregation and release reactions. J Immunol 116: 1289-1294.

Fiedel BA, Gewurz H (1976b) Effects of C-reactive protein on platelet function. II. Inhibition by CRP of platelet reactivities stimulated by poly-L-lysine, ADP, epinephrine, and collagen. J Immunol 117: 1073-1078.
Fiedel BA, Simpson RM, Gewurz H (1977) Effects of Creactive protein on platelet function. III. The role of cAMP, contractile elements, and prostaglandin metabolism in CRP-induced inhibition of platelet aggregation and secretion. J Immunol 119: 877-882.

Fiedel BA, Simpson RM, Gewurz H (1982) Activation of platelets by modified C-reactive protein. Immunology 45: 439-447.

Gabay C, Kushner I (1999) Acute-phase proteins and other systemic responses to inflammation. $N$ Engl J Med 340: 448-454.

Ganter U, Arcone R, Toniatti C, Morrone G, Ciliberto G (1989) Dual control of C-reactive protein gene expression by interleukin-1 and interleukin-6. EMBO J 8: 3773-3779.

Garlanda C, Bottazzi B, Bastone A, Mantovani A (2005) Pentraxins at the crossroads between innate immunity, inflammation, matrix deposition, and female fertility. Annu Rev Immunol 23: 337-366.

Gershov D, Kim S, Brot N, Elkon KB (2000) C-Reactive protein binds to apoptotic cells, protects the cells from assembly of the terminal complement components, and sustains an antiinflammatory innate immune response: implications for systemic autoimmunity. J Exp Med 192: 1353-1364.

Gewurz H, Mold C, Siegel J, Fiedel B (1982) C-reactive protein and the acute phase response. Adv Intern Med 27: 345-372.

Hanriot D, Bello G, Ropars A, Seguin-Devaux C, Poitevin G, Grosjean S, Latger-Cannard V, Devaux Y, Zannad F, Regnault V, Lacolley P, Mertes PM, Hess K, Longrois D (2008) C-reactive protein induces pro- and anti-inflammatory effects, including activation of the liver $X$ receptor $\alpha$, on human monocytes. Thromb Haemost 99: 558-569.

Hattori Y, Matsumura M, Kasai K (2003) Vascular smooth muscle cell activation by C-reactive protein. Cardiovasc Res 58: 186-195.

Haverkate F, Thompson SG, Pyke SD, Gallimore JR, Pepys MB (1997) Production of C-reactive protein and risk of coronary events in stable and unstable angina. European Concerted Action on Thrombosis and Disabilities Angina Pectoris Study Group. Lancet 349: 462-466.

Heuertz RM, Schneider GP, Potempa LA, Webster RO (2005) Native and modified C-reactive protein bind different receptors on human neutrophils. Int J Biochem Cell Biol 37: 320-335.

Hirschfield GM, Gallimore JR, Kahan MC, Hutchinson WL, Sabin CA, Benson GM, Dhillon AP, Tennent GA, Pepys MB (2005) Transgenic human C-reactive protein is not proatherogenic in apolipoprotein E-deficient mice. Proc Natl Acad Sci USA 102: 8309-8314.

Hurlimann J, Thorbecke GJ, Hochwald GM (1966) The liver as the site of C-reactive protein formation. J Exp Med 123: 365-378.

Jabs WJ, Logering BA, Gerke P, Kreft B, Wolber EM, Klinger $\mathrm{MH}$, Fricke L, Steinhoff J (2003) The kidney as a second site of human C-reactive protein formation in vivo. Eur J Immunol 33: 152-161.

Ji SR, Wu Y, Potempa LA, Qiu Q, Zhao J (2006a) Interactions of C-reactive protein with low-density lipoproteins: Implications for an active role of modified C-reactive protein in atherosclerosis. Int J Biochem Cell Biol 38: 648-661.

Ji SR, Wu Y, Potempa LA, Liang YH, Zhao J (2006b) Effect of modified C-reactive protein on complement activation: a possible complement regulatory role of modified or monomeric C-reactive protein in atherosclerotic lesions. Arterioscler Thromb Vasc Biol 26: 935-941. 
Ji SR, Wu Y, Zhu L, Potempa LA, Sheng FL, Lu W, Zhao J (2007) Cell membranes and liposomes dissociate C-reactive protein (CRP) to form a new, biologically active structural intermediate: $\mathrm{mCRP}_{\mathrm{m}}$. FASEB J 21: 284-294.

Jiang HX, Siegel JN, Gewurz H (1991) Binding and complement activation by $\mathrm{C}$-reactive protein via the collagen-like region of $\mathrm{C} 1 \mathrm{q}$ and inhibition of these reactions by monoclonal antibodies to C-reactive protein and C1q. J Immunol 146: 2324-2330.

Kathiresan S, Larson MG, Vasan RS, Guo CY, Gona P, Keaney JF Jr, Wilson PW, Newton-Cheh C, Musone SL, Camargo AL, Drake JA, Levy D, O'Donnell CJ, Hirschhorn JN, Benjamin EJ (2006) Contribution of clinical correlates and ${ }^{13} \mathrm{C}$-reactive protein gene polymorphisms to interindividual variability in serum C-reactive protein level. Circulation 113: 1415-1423.

Kawanami D, Maemura K, Takeda N, Harada T, Nojiri T, Saito T, Manabe I, Imai Y, Nagai R (2006) C-reactive protein induces VCAM-1 gene expression through NF$\mathrm{\kappa B}$ activation in vascular endothelial cells. Atherosclerosis 185: 39-46.

Kew RR, Hyers TM, Webster RO (1990) Human C-reactive protein inhibits neutrophil chemotaxis in vitro: possible implications for the adult respiratory distress syndrome. J Lab Clin Med 115: 339-345.

Khreiss T, Jozsef L, Hossain S, Chan JS, Potempa LA, Filep JG (2002a) Loss of pentameric symmetry of C-reactive protein is associated with delayed apoptosis of human neutrophils. J Biol Chem 277: 40775-40781.

Khreiss T, Jozsef L, Potempa LA, Filep JG (2002b) Loss of pentameric symmetry in C-reactive protein induces interleukin-8 secretion through peroxynitrite signaling in human neutrophils. Circ Res 97: 690-697.

Khreiss T, Jozsef L, Potempa LA, Filep JG (2004a) Conformational rearrangement in C-reactive protein is required for proinflammatory actions on human endothelial cells. Circulation 109: 2016-2022.

Khreiss T, Jozsef L, Potempa LA, Filep JG (2004b) Opposing effects of C-reactive protein isoforms on shear-induced neutrophil-platelet adhesion and neutrophil aggregation in whole blood. Circulation 110: 2713-2720.

Koenig W, Sund M, Frohlich M, Fischer HG, Lowel H, Doring A, Hutchinson WL, Pepys MB (1999) C-Reactive protein, a sensitive marker of inflammation, predicts future risk of coronary heart disease in initially healthy middle-aged men: results from the MONICA (Monitoring Trends and Determinants in Cardiovascular Disease) Augsburg Cohort Study, 1984 to 1992. Circulation 99: 237-242.

Kovacs A, Green F, Hansson LO, Lundman P, Samnegard A, Boquist S, Ericsson CG, Watkins H, Hamsten A, Tornvall P (2005) A novel common single nucleotide polymorphism in the promoter region of the C-reactive protein gene associated with the plasma concentration of C-reactive protein. Atherosclerosis 178: 193-198.

Kovacs A, Tornvall P, Nilsson R, Tegner J, Hamsten A, Bjorkegren J (2007) Human C-reactive protein slows atherosclerosis development in a mouse model with human-like hypercholesterolemia. Proc Natl Acad Sci USA 104: 13768-13773.

Kresl JJ, Potempa LA, Anderson BE (1998) Conversion of native oligomeric to a modified monomeric form of human C-reactive protein. Int J Biochem Cell Biol 30: 1415-1426.

Kresl JJ, Potempa LA, Anderson B, Radosevich JA (1999) Inhibition of mouse mammary adenocarcinoma (EMT6) growth and metastases in mice by a modified form of C-reactive protein. Tumour Biol 20: 72-87.
Lafuente N, Azcutia V, Matesanz N, Cercas E, RodriguezManas L, Sanchez-Ferrer CF, Peiro C (2005) Evidence for sodium azide as an artifact mediating the modulation of inducible nitric oxide synthase by C-reactive protein. J Cardiovasc Pharmacol 45: 193-196.

Li L, Roumeliotis N, Sawamura T, Renier G (2004) C-reactive protein enhances LOX-1 expression in human aortic endothelial cells: relevance of LOX-1 to C-reactive protein-induced endothelial dysfunction. Circ Res 95: 877-883.

Liuzzo G, Biasucci LM, Gallimore JR, Grillo RL, Rebuzzi AG, Pepys MB, Maseri A (1994) The prognostic value of C-reactive protein and serum amyloid a protein in severe unstable angina. N Engl J Med 331: 417-424.

Marnell LL, Mold C, Volzer MA, Burlingame RW, Du Clos TW (1995) C-reactive protein binds to Fc $\gamma R$ In transfected COS cells. J Immunol 155: 2185-2193.

Marumo T, Schini-Kerth VB, Fisslthaler B, Busse R (1997) Platelet-derived growth factor-stimulated superoxide anion production modulates activation of transcription factor NF- $\mathrm{KB}$ and expression of monocyte chemoattractant protein 1 in human aortic smooth muscle cells. Circulation 96: 2361-2367.

McGrath FD, Brouwer MC, Arlaud GJ, Daha MR, Hack CE, Roos A (2006) Evidence that complement protein $\mathrm{C} 1 \mathrm{q}$ interacts with C-reactive protein through its globular head region. J Immunol 176: 2950-2957.

Mehta PK, Griendling KK (2007) Angiotensin II cell signaling: physiological and pathological effects in the cardiovascular system. Am J Physiol Cell Physiol 292: C82-C97.

Mine S, Fujisaki T, Suematsu M, Tanaka Y (2001) Activated platelets and endothelial cell interaction with neutrophils under flow conditions. Intern Med 40: 10851092.

Muller H, Fehr J (1986) Binding of C-reactive protein to human polymorphonuclear leukocytes: evidence for association of binding sites with Fc receptors. J Immunol 136: 2202-2207.

Nilsson J (2005) CRP - marker or maker of cardiovascular disease? Arterioscler Thromb Vasc Biol 25: 1527-1528.

Nunomura W, Hatakeyama M (1990) Binding of low density lipoprotein (LDL) to C-reactive protein (CRP): a possible binding through apolipoprotein B in LDL at phosphorylcholine-binding site of CRP. Hokkaido Igaku Zasshi 65: 474-480.

Osmand AP, Friedenson B, Gewurz H, Painter RH, Hofmann T, Shelton E (1977) Characterization of C-reactive protein and the complement subcomponent $\mathrm{C} 1 \mathrm{t}$ as homologous proteins displaying cyclic pentameric symmetry (pentraxins). Proc Natl Acad Sci USA 74: 739-743.

Pasceri V, Willerson JT, Yeh ET (2000) Direct proinflammatory effect of C-reactive protein on human endothelial cells. Circulation 102: 2165-2168.

Pasceri V, Cheng JS, Willerson JT, Yeh ET (2001) Modulation of C-reactive protein-mediated monocyte chemoattractant protein-1 induction in human endothelial cells by anti-atherosclerosis drugs. Circulation 103: 2531-2534.

Paul A, Ko KW, Li L, Yechoor V, McCrory MA, Szalai AJ, Chan L (2004) C-reactive protein accelerates the progression of atherosclerosis in apolipoprotein E-deficient mice. Circulation 109: 647-655.

Pepys MB (1981) C-reactive protein fifty years on. Lancet 1: 653-657.

Pepys MB (2005) CRP or not CRP? That is the question. Arterioscler Thromb Vasc Biol 25: 1091-1094. 
Pepys MB (2008) C-reactive protein is neither a marker nor a mediator of atherosclerosis. Nat Clin Pract Nephrol 4: 234-235.

Pepys MB, Hawkins PN, Kahan MC, Tennent GA, Gallimore JR, Graham D, Sabin CA, Zychlinsky A, de Diego J (2005) Proinflammatory effects of bacterial recombinant human C-reactive protein are caused by contamination with bacterial products, not by C-reactive protein itself. Circ Res 97: e97-e103.

Pepys MB, Hirschfield GM, Tennent GA, Gallimore JR, Kahan MC, Bellotti V, Hawkins PN, Myers RM, Smith MD, Polara A, Cobb AJ, Ley SV, Aquilina JA, Robinson CV, Sharif I, Gray GA, Sabin CA, Jenvey MC, Kolstoe SE, Thompson D, Wood SP (2006) Targeting C-reactive protein for the treatment of cardiovascular disease. $\mathrm{Na}$ ture 440: 1217-1221.

Perkins SJ, Nealis AS, Sutton BJ, Feinstein A (1991) Solution structure of human and mouse immunoglobulin $\mathrm{M}$ by synchrotron X-ray scattering and molecular graphics modelling. A possible mechanism for complement activation. J Mol Biol 221: 1345-1366.

Potempa LA, Maldonado BA, Laurent P, Zemel ES, Gewurz H (1983) Antigenic, electrophoretic and binding alterations of human C-reactive protein modified selectively in the absence of calcium. Mol Immunol 20: 1165-1175.

Potempa LA, Siegel JN, Fiedel BA, Potempa RT, Gewurz $\mathrm{H}$ (1987) Expression, detection and assay of a neoantigen (Neo-CRP) associated with a free, human C-reactive protein subunit. Mol Immunol 24: 531-541.

Potempa LA, Motie M, Wright KE, Crump BL, Radosevich JA, Sakai N, Lai G, Tanaka K, Kojima E, Tsuboi A (1996) Stimulation of megakaryocytopoiesis in mice by human modified C-reactive protein (mCRP). Exp Hematol 24: 258-264.

Ramage L, Proudfoot L, Guy K (2004) Expression of Creactive protein in human lung epithelial cells and upregulation by cytokines and carbon particles. Inhal Toxicol 16: 607-613.

Reifenberg K, Lehr HA, Baskal D, Wiese E, Schaefer SC, Black S, Samols D, Torzewski M, Lackner KJ, Husmann M, Blettner M, Bhakdi S (2005) Role of C-reactive protein in atherogenesis: can the apolipoprotein E knockout mouse provide the answer? Arterioscler Thromb Vasc Biol 25: 1641-1646.

Reitz C, Berger K, de Maat MP, Stoll M, Friedrichs F, Kardys I, Witteman JC, Breteler MM (2007) CRP gene haplotypes, serum CRP, and cerebral small-vessel disease: the Rotterdam Scan Study and the MEMO Study. Stroke 38: 2356-2359.

Ridker PM (2002a) Inflammatory biomarkers, statins, and the risk of stroke: cracking a clinical conundrum. Circulation 105: 2583-2585.

Ridker PM, Cushman M, Stampfer MJ, Tracy RP, Hennekens CH (1997) Inflammation, aspirin, and the risk of cardiovascular disease in apparently healthy men. $N$ Engl J Med 336: 973-979.

Ridker PM, Hennekens CH, Buring JE, Rifai N (2000a) Creactive protein and other markers of inflammation in the prediction of cardiovascular disease in women. $N$ Engl J Med 342: 836-843.

Ridker PM, Rifai N, Stampfer MJ, Hennekens CH (2000b) Plasma concentration of interleukin- 6 and the risk of future myocardial infarction among apparently healthy men. Circulation 101: 1767-1772.

Ridker PM, Stampfer MJ, Rifai N (2001) Novel risk factors for systemic atherosclerosis: a comparison of C-reactive protein, fibrinogen, homocysteine, lipoprotein(a), and standard cholesterol screening as predictors of peripheral arterial disease. JAMA 285: 2481-2485.

Ridker PM, Rifai N, Rose L, Buring JE, Cook NR (2002b) Comparison of C-reactive protein and low-density lipoprotein cholesterol levels in the prediction of first cardiovascular events. N Engl J Med 347: 1557-1565.

Ridker PM, Buring JE, Cook NR, Rifai N (2003) C-reactive protein, the metabolic syndrome, and risk of incident cardiovascular events: an 8-year follow-up of 14 719 initially healthy American women. Circulation 107: 391-397.

Saeland E, van Royen A, Hendriksen K, Vile-Weekhout H, Rijkers GT, Sanders LA, van de Winkel JG (2001) Human C-reactive protein does not bind to Fc $\gamma$ RIIa on phagocytic cells. J Clin Invest 107: 641-643.

Salonen EM, Vartio T, Hedman K, Vaheri A (1984) Binding of fibronectin by the acute phase reactant C-reactive protein. J Biol Chem 259: 1496-1501.

Santoso S, Sachs UJ, Kroll H, Linder M, Ruf A, Preissner KT, Chavakis T (2002) The junctional adhesion molecule 3 (JAM-3) on human platelets is a counterreceptor for the leukocyte integrin Mac-1. J Exp Med 196: 679-691.

Saxena U, Nagpurkar A, Dolphin PJ, Mookerjea S (1987) A study on the selective binding of apoprotein B- and Econtaining human plasma lipoproteins to immobilized rat serum phosphorylcholine-binding protein. J Biol Chem 262: 3011-3016.

Schwedler SB, Guderian F, Dammrich J, Potempa LA, Wanner C (2003) Tubular staining of modified C-reactive protein in diabetic chronic kidney disease. Nephrol Dial Transplant 18: 2300-2307.

Schwedler SB, Amann K, Wernicke K, Krebs A, Nauck M, Wanner C, Potempa LA, Galle J (2005) Native C-reactive protein increases whereas modified C-reactive protein reduces atherosclerosis in apolipoprotein E-knockout mice. Circulation 112: 1016-1023.

Schwedler SB, Kuhlencordt PJ, Ponnuswamy PP, Hatiboglu G, Quaschning T, Widder J, Wanner C, Potempa LA, Galle J (2007) Native C-reactive protein induces endothelial dysfunction in ApoE ${ }^{-/}$mice: implications for iNOS and reactive oxygen species. Atherosclerosis 195: e76-e84.

Scirica BM, Morrow DA (2006) Is C-reactive protein an innocent bystander or proatherogenic culprit? The verdict is still out. Circulation 113: 2128-2134.

Shantsila E, Watson T, Lip GY (2007) Endothelial progenitor cells in cardiovascular disorders. J Am Coll Cardiol 49: 741-752.

Shrive AK, Cheetham GM, Holden D, Myles DA, Turnell WG, Volanakis JE, Pepys MB, Bloomer AC, Greenhough TJ (1996) Three dimensional structure of human C-reactive protein. Nat Struct Biol 3: 346-354.

Simon DI, Chen Z, Xu H, Li CQ, Dong J, McIntire LV, Ballantyne CM, Zhang L, Furman MI, Berndt MC, Lopez JA (2000) Platelet glycoprotein Ib $\alpha$ is a counterreceptor for the leukocyte integrin Mac-1 (CD11b/CD18). J Exp Med 192: 193-204.

Singh U, Devaraj S, Jialal I (2005) C-reactive protein decreases tissue plasminogen activator activity in human aortic endothelial cells: evidence that C-reactive protein is a procoagulant. Arterioscler Thromb Vasc Biol 25: 2216-2221.

Singh SK, Suresh MV, Prayther DC, Moorman JP, Rusinol AE, Agrawal A (2008a) C-reactive protein-bound enzymatically modified low-density lipoprotein does not transform macrophages into foam cells. J Immunol 180: 4316-4322. 
Singh SK, Suresh MV, Prayther DC, Moorman JP, Rusinol AE, Agrawal A (2008b) Phosphoethanolamine-complexed C-reactive protein: a pharmacological-like macromolecule that binds to native low-density lipoprotein in human serum. Clin Chim Acta 394: 94-98.

Singh SK, Suresh MV, Voleti B, Agrawal A (2008c) The connection between $\mathrm{C}$-reactive protein and atherosclerosis. Ann Med 40: 110-120.

Stein MP, Edberg JC, Kimberly RP, Mangan EK, Bharadwaj D, Mold C, Du Clos TW (2000) C-reactive protein binding to Fc $\gamma$ RIIa on human monocytes and neutrophils is allele-specific. J Clin Invest 105: 369-376.

Suh W, Kim KL, Choi JH, Lee YS, Lee JY, Kim JM, Jang HS, Shin IS, Lee JS, Byun J, Jeon ES, Kim DK (2004) $\mathrm{C}$-reactive protein impairs angiogenic functions and decreases the secretion of arteriogenic chemo-cytokines in human endothelial progenitor cells. Biochem Biophys Res Commun 321: 65-71.

Sun H, Koike T, Ichikawa T, Hatakeyama K, Shiomi M, Zhang B, Kitajima S, Morimoto M, Watanabe T, Asada Y, Chen YE, Fan J (2005) C-reactive protein in atherosclerotic lesions: its origin and pathophysiological significance. Am J Pathol 167: 1139-1148.

Suresh MV, Singh SK, Ferguson DA Jr, Agrawal A (2006) Role of the property of C-reactive protein to activate the classical pathway of complement in protecting mice from pneumococcal infection. I Immunol 176: 4369-4374.

Swafford AN Jr, Bratz IN, Knudson JD, Rogers PA, Timmerman JM, Tune JD, Dick GM (2005) C-reactive protein does not relax vascular smooth muscle: effects mediated by sodium azide in commercially available preparations. Am J Physiol Heart Circ Physiol 288: H1786-H1795.

Swanson SJ, McPeek MM, Mortensen RF (1989) Characteristics of the binding of human C-reactive protein (CRP) to laminin. J Cell Biochem 40: 121-132.

Szalai AJ, McCrory MA (2002) Varied biologic functions of C-reactive protein: lessons learned from transgenic mice. Immunol Res 26: 279-287.

Taskinen S, Kovanen PT, Jarva H, Meri S, Pentikainen MO (2002) Binding of C-reactive protein to modified lowdensity-lipoprotein particles: identification of cholesterol as a novel ligand for C-reactive protein. Biochem J 367: 403-412.

Taylor KE, Giddings JC, van den Berg CW (2005) C-reactive protein-induced in vitro endothelial cell activation is an artefact caused by azide and lipopolysaccharide. Arterioscler Thromb Vasc Biol 25: 1225-1230.

Tennent GA, Hutchinson WL, Kahan MC, Hirschfield GM, Gallimore JR, Lewin J, Sabin CA, Dhillon AP, Pepys MB (2008) Transgenic human CRP is not pro-atherogenic, pro-atherothrombotic or pro-inflammatory in apoE ${ }^{-/}$mice. Atherosclerosis 196: 248-255.

Thurberg BL, Collins T (1998) The nuclear factor B/inhibitor of kappa B autoregulatory system and atherosclerosis. Curr Opin Lipidol 9: 387-396.

Tillett WS, Francis T Jr (1930) Serological reactions in pneumonia with a non-protein somatic fraction of pneumococcus. J Exp Med 52: 561-571.

Torzewski J (2005) C-reactive protein and atherogenesis: new insights from established animal models. Am J Pathol 167: 923-925.

Torzewski J, Torzewski M, Bowyer DE, Frohlich M, Koenig W, Waltenberger J, Fitzsimmons C, Hombach V (1998) C-reactive protein frequently colocalizes with the terminal complement complex in the intima of early atherosclerotic lesions of human coronary arteries. Arterioscler Thromb Vasc Biol 18: 1386-1392.
Trion A, de Maat MP, Jukema JW, van der Laarse A, Maas MC, Offerman EH, Havekes LM, Szalai AJ, Princen HM, Emeis JJ (2005) No effect of C-reactive protein on early atherosclerosis development in apolipoprotein E*3-leiden/human C-reactive protein transgenic mice. Arterioscler Thromb Vasc Biol 25: 1635-1640.

Tseng J, Mortensen RF (1988) Binding of human C-reactive protein (CRP) to plasma fibronectin occurs via the phosphorylcholine-binding site. Mol Immunol 25: 679686.

Vaith P, Potempa LA (2000) Deposition of modified or native C-reactive protein in atherosclerotic arteries? Arterioscler Thromb Vasc Biol 20: 1173-1174.

van den Berg CW, Taylor KE, Lang D (2004) C-reactive protein-induced in vitro vasorelaxation is an artefact caused by the presence of sodium azide in commercial preparations. Arterioscler Thromb Vasc Biol 24: e168e171.

van Tits L, de Graaf J, Toenhake H, van Heerde W, Stalenhoef A (2005) C-reactive protein and annexin A5 bind to distinct sites of negatively charged phospholipids present in oxidized low-density lipoprotein. Arterioscler Thromb Vasc Biol 25: 717-722.

Venugopal SK, Devaraj S, Yuhanna I, Shaul P, Jialal I (2002) Demonstration that C-reactive protein decreases eNOS expression and bioactivity in human aortic endothelial cells. Circulation 106: 1439-1441.

Venugopal SK, Devaraj S, Jialal I (2003) C-reactive protein decreases prostacyclin release from human aortic endothelial cells. Circulation 108: 1676-1678.

Verma S, Li SH, Badiwala MV, Weisel RD, Fedak PW, Li RK, Dhillon B, Mickle DA (2002a) Endothelin antagonism and interleukin-6 inhibition attenuate the proatherogenic effects of C-reactive protein. Circulation 105: 1890-1896.

Verma S, Wang CH, Li SH, Dumont AS, Fedak PW, Badiwala MV, Dhillon B, Weisel RD, Li RK, Mickle DA, Stewart DJ (2002b) A self-fulfilling prophecy: C-reactive protein attenuates nitric oxide production and inhibits angiogenesis. Circulation 106: 913-919.

Verma S, Badiwala MV, Weisel RD, Li SH, Wang CH, Fedak PW, Li RK, Mickle DA (2003) C-reactive protein activates the nuclear factor- $\mathrm{KB}$ signal transduction pathway in saphenous vein endothelial cells: implications for atherosclerosis and restenosis. J Thorac Cardiovasc Surg 126: 1886-1891.

Verma S, Kuliszewski MA, Li SH, Szmitko PE, Zucco L, Wang CH, Badiwala MV, Mickle DA, Weisel RD, Fedak PW, Stewart DJ, Kutryk MJ (2004a) C-reactive protein attenuates endothelial progenitor cell survival, differentiation, and function: further evidence of a mechanistic link between C-reactive protein and cardiovascular disease. Circulation 109: 2058-2067.

Verma S, Szmitko PE, Yeh ET (2004b) C-reactive protein: structure affects function. Circulation 109: 1914-1917.

Verma S, Devaraj S, Jialal I (2006) Is C-reactive protein an innocent bystander or proatherogenic culprit? C-reactive protein promotes atherothrombosis. Circulation 113: 2135-2150.

Vlaicu R, Rus HG, Niculescu F, Cristea A (1985) Immunoglobulins and complement components in human aortic atherosclerotic intima. Atherosclerosis 55: 35-50.

Volanakis JE, Wirtz KW (1979) Interaction of C-reactive protein with artificial phosphatidylcholine bilayers. $\mathrm{Na}$ ture 281: 155-157.

Voleti B, Agrawal A (2006) Statins and nitric oxide reduce $\mathrm{C}$-reactive protein production while inflammatory conditions persist. Mol Immunol 43: 891-896. 
Wang HW, Sui SF (2001) Dissociation and subunit rearrangement of membrane-bound human C-reactive proteins. Biochem Biophys Res Commun 288: 75-79.

Wang CH, Li SH, Weisel RD, Fedak PW, Dumont AS, Szmitko P, Li RK, Mickle DA, Verma S (2003) C-reactive protein upregulates angiotensin type 1 receptors in vascular smooth muscle. Circulation 107: 1783-1790.

Wang Q, Hunt SC, Xu Q, Chen YE, Province MA, Eckfeldt JH, Pankow JS, Song Q (2006) Association study of CRP gene polymorphisms with serum CRP level and cardiovascular risk in the NHLBI Family Heart Study. Am J Physiol Heart Circ Physiol 291: H2752-H2757.

Whisler RL, Proctor VK, Downs EC, Mortensen RF (1986) Modulation of human monocyte chemotaxis and procoagulant activity by human C-reactive protein (CRP). Lymphokine Res 5: 223-228.

Whitehead AS, Bruns GA, Markham AF, Colten HR, Woods DE (1983) Isolation of human C-reactive protein complementary DNA and localization of the gene to chromosome 1. Science 221: 69-71.

Woollard KJ, Phillips DC, Griffiths HR (2002) Direct modulatory effect of C-reactive protein on primary human monocyte adhesion to human endothelial cells. Clin Exp Immunol 130: 256-262.

Xie L, Chang L, Guan Y, Wang X (2005) C-reactive protein augments interleukin-8 secretion in human peripheral blood monocytes. J Cardiovasc Pharmacol 46: 690-696.

Yap SH, Moshage HJ, Hazenberg BP, Roelofs HM, Bijzet J, Limburg PC, Aarden LA, van Rijswijk MH (1991) Tumor necrosis factor (TNF) inhibits interleukin (IL)-1 and/or IL-6 stimulated synthesis of C-reactive protein (CRP) and serum amyloid A (SAA) in primary cultures of human hepatocytes. Biochim Biophys Acta 1091: 405-408.

Yaron G, Brill A, Dashevsky O, Yosef-Levi IM, Grad E, Danenberg HD, Varon D (2006) C-reactive protein promotes platelet adhesion to endothelial cells: a potential pathway in atherothrombosis. Br J Haematol 134: 426431.

Yasojima K, Schwab C, McGeer EG, McGeer PL (2000) Human neurons generate $\mathrm{C}$-reactive protein and amyloid P: upregulation in Alzheimer's disease. Brain Res 887: 80-89.

Yasojima K, Schwab C, McGeer EG, McGeer PL (2001) Generation of C-reactive protein and complement components in atherosclerotic plaques. Am J Pathol 158: 1039-1051.

Zacho J, Tybjaerg-Hansen A, Jensen JS, Grande P, Sillesen H, Nordestgaard BG (2008) Genetically elevated C-reactive protein and ischemic vascular disease. $N$ Engl J Med 359: 1897-1908.

Zeller JM, Sullivan BL (1992) C-reactive protein selectively enhances the intracellular generation of reactive oxygen products by IgG-stimulated monocytes and neutrophils. J Leukoc Biol 52: 449-455.

Zouki C, Haas B, Chan JS, Potempa LA, Filep JG (2001) Loss of pentameric symmetry of C-reactive protein is associated with promotion of neutrophil-endothelial cell adhesion. J Immunol 167: 5355-5361. 